\title{
Effect of Auto-exhaust Emissions on Seed Germination of Tree Species Growing along Roadside in Industrial Area of Himachal Pradesh, India
}

\author{
Nitika Sharma*, Mohinder Singh and S. K. Bhardwaj
}

Dept. of Environmental Science, Dr. Y. S. P. University of Horticulture and Forestry, Nauni, Solan, H. P. (173 230), India

\section{Corresponding Author}

Nitika Sharma

e-mail: sharmanitika665@gmail.com

\author{
Article History \\ Article ID: IJEP0225 \\ Received in $24^{\text {th }}$ January, 2018 \\ Received in revised form $3^{\text {rd }}$ March, 2018 \\ Accepted in final form 25 $5^{\text {th }}$ March, 2018
}

\begin{abstract}
Effect of auto-exhaust emissions on the seed germination of tree species growing along roadside was studied at four locations viz., National Highway 21-A (Baddi), Baddi-Barotiwala link road, Kalka-Charnia link road and 200m away from road in Kalka-Charnia Link Road (Control) in BBN industrial area of Himachal Pradesh, India. The seed germination in all the tree species under study decreased in sites where seeds were collected from roadside trees as compared to control where seeds were collected $200 \mathrm{~m}$ away from road in Kalka-Charnia link road. The germination (\%) in Leucaena leucocephala was 4.0, 11.5 and 34.0 in seeds collected from National Highway 21-A (Baddi), Baddi-Barotiwala link road and Kalka-Charnia link road, respectively, against $43.0 \%$ seed germination in control. In Toona ciliata, the seed germination was 95.0, 97.0 and 96.5\% in National Highway 21-A (Baddi), Baddi-Barotiwala link road and Kalka-Charnia link road, respectively, against 99.0\% in control. In Dalbergia sissoo the germination ranged between 94.5 and $97.5 \%$ in roadside sites against $99.5 \%$ germination in control. The germination energy, germination value and germination speed were also found lower in roadside sites as compared to control in all the species. L. leucocephala has been proved more sensitive to auto-exhaust pollutants as compared to $T$. ciliata and D. sissoo. Among different sites, National Highway 21- A was found most polluted followed by Baddi-Barotiwala link road and Kalka-Charnia link road.
\end{abstract}

Keywords: Auto-exhaust, germination energy, Leucaena leucocephala, seed germination, tree species

\section{Introduction}

Air pollution in India has increased rapidly because of intensive population growth, increase in the numbers of vehicles, use of fuels with poor environmental performance, badly mentioned transportation systems, poor land use pattern, industrialization, and above all, ineffective environmental regulations (Chattopadhyay et al., 2010) .

It deteriorates ecological condition and can be defined as the fluctuation in any atmospheric constituent from the value that would have existed without human activity (Tripathi and Gautam, 2007). Motor vehicles accounts for $60-70 \%$ of the pollution found in an urban environment (Dwivedi et al., 2008). Air pollution has become a major problem arising mainly from industrialization, unplanned urbanization and alarming increase in vehicle fleet as a result of population growth. The number of automobiles has increased with rapid development of human civilization, which ultimately deteriorates the air quality. The use of automobile is growing fast globally and with much greater pace in developing countries. The problem posed with vehicles is due to discharge of various types of pollutants which affect the vegetation around. Infact, vehicular emission is much greater than that caused by emission of dust and poisonous gases by different type of factories. Road traffic is considered as one of the most important sources of air and noise pollution.

Dense traffic releases detrimental exhaust gases and toxic pollutants like unburnt and partially burnt hydrocarbons and other elements that are contained in petrol are polluting the city environment (Iqbal et al., 2001). The increasing number of industries and automobiles are continuously adding toxic gases and various substances including gases (Sulphur dioxide, nitrogen oxides, carbon monoxides, hydrocarbons etc.) particulate matter (smoke, dust, fumes, aerosols etc.) radioactive material and many others to our environment (Das and Prasad, 2010).

These air pollutants may interfere with the biological process relating to general metabolism, photosynthetic activities, mitochondrial respiration and stomatal clogging of plants (Miles et al., 1972; Ahmed and Qadir, 1975; Abdullah and Iqbal, 1991). The plants can be affected by pollutants directly via leaves and indirectly by soil acidification. It has also been reported that when exposed to air pollutants, most plants experience physiological changes before exhibiting visible damage to leaves. 
Shafiq and Iqbal (2007) have found highest reductions in seed germination in Peltophorum pterocarpuma roadside ornamental tree where the seeds collected from extremely polluted area, followed by very much polluted, polluted, little polluted and unpolluted areas. They linked the reduction in seed germination of $P$. pterocarpum to the development of unhealthy seeds by trees due to roadside pollution. Similarly, Shafiq and lqbal (2012) also reported lower germination of Cassia siamea seeds collected from polluted areas compared to clean area. The extent of reduction in seeds germination was related to amount of pollution in the study sites. They further observed that seedling growth of plants raised from seeds from polluted area had lower tolerance to heavy metals as compared to unpolluted area. Mondal et al. (2014) have proved adverse effects of black soot collected from exhaust tubes of 15 years old petrol and diesel operated vehicles on seed germination and bio-chemical parameters of Gram. Seyyed and Haniyeh (2014) have studied the impact of ambient air pollution on some biological factors in Prosopis juliflora plants using two sites; control and polluted which was around one of the oil fields in south west of Iran. Various morphological and biochemical characteristics of the plants were studied in both the sites and compared with each other. Plants exposed to pollution showed lower leaf area, petiole length, chlorophylls, carotenoids and soluble carbohydrate contents as compared to plants growing in control site.

Nesamani (2010) has shown that pollutants derived from the auto emissions can directly affect the plant ability to produce and store food in the seeds. The effect of air pollutants generated from the exhaust of industries and automobiles on the chlorophyll content of leaves has been studied by Sumitraet al. (2013). Therefore; the investigations were carried on the effect auto-exhaust on seed germination of tree species growing in roadside in BBN industrial area of Himachal Pradesh.

\section{Materials and Methods}

The study was conducted in Baddi-Barotiwala and Nalagarh (BBN) industrial area located in the foothills of Shiwalik hills. The study area lies on the border of Himachal Pradesh and Haryana states. Baddi, Barotiwala and Nalagarh area has emerged as a major industrial hub in Himachal Pradesh, situated in south west region of Solan and is about $45 \mathrm{~km}$ from Solan. The study area is situated at an altitude of 422-448 $\mathrm{m}$ above mean sea level and lies between $30^{\circ} 55^{\prime}$ to $31^{\circ} 02^{\prime}$ $\mathrm{N}$ latitude and $76^{\circ} 42^{\prime}$ to $76^{\circ} 49^{\prime} \mathrm{E}$ longitude. The BBN region of Himachal Pradesh has subtropical climate with winter season commencing from November to February, summer season from March to June followed by the monsoon period extending from July to September. Average rainfall in the district is about $1150 \mathrm{~mm}$. In order to study the vegetation distribution, amount of pollution and to select the study sites a survey was conducted in the region. Based on the survey four sites were selected for study National Highway $21 \mathrm{~A}$; in Baddi industrial area, Baddi-Barotiwala Link Road, KalkaCharnia Link Road and Control; $200 \mathrm{~m}$ away from road in Kalka-Charnia Link Road.

The seeds of three tree species, L. leucocephala, T. ciliata and $D$. sissoo at all the selected sites were collected during growing seasons and studied for different quality parameters like seed germination, germination energy, germination value and germination speed. The seed germination studies were conducted by keeping the seeds of test species in Petri plates lined with moist germination paper. Five replications with 40 seeds per replication were maintained for eeach tree in every site. The Petri plates with seeds were incubated in a germinator at $25 \pm 10^{\circ} \mathrm{C}$. The germination (\%) was calculated as per the ISTA procedure (ISTA, 1985). Other seed germination parameters like germination (\%), germination energy, germination value and germination speed were calculated. The data on various seed germination parameters were analysed by using completely randomized design.

\section{Results and Discussion}

3.1. Variations in seed germination parameters of Leucaena leucocephala growing along roadside in BBN industrial area of Himachal Pradesh

The seed germination in L. leucocephala was found to be 4.0, 11.5 and $34.0 \%$ in National Highway 21-A, Baddi Barotiwala link road and Kalka Charnia link road, respectively, against $43.0 \%$ in control where the seeds were collected 200 m away from road in Kalka Charnia link road (Table 1). No significant differences in seed germination were recorded in Kalka Charnia link road and control treatment. Whereas, seed germination was found significantly lowest i.e. 4.0 in National Highway 21-A Baddi.

The lowest germination energy was also recorded in National Highway 21-A i.e. 3.0, followed by 6.0 in Baddi Barotiwala

Table 1: Variations in seed germination parameters of Leucaena leucocephala growing along roadside in BBN industrial area of Himachal Pradesh

\begin{tabular}{|c|c|c|c|c|}
\hline Sites & $\begin{array}{c}\text { Germi- } \\
\text { nation } \\
(\%)\end{array}$ & $\begin{array}{l}\text { Germi- } \\
\text { nation } \\
\text { energy }\end{array}$ & $\begin{array}{l}\text { Germi- } \\
\text { nation } \\
\text { value }\end{array}$ & $\begin{array}{l}\text { Germi- } \\
\text { nation } \\
\text { speed }\end{array}$ \\
\hline $\begin{array}{l}\text { National highway } \\
\text { 21-A (Baddi) }\end{array}$ & $\begin{array}{c}4.0 \\
(8.93)\end{array}$ & $\begin{array}{c}3.0 \\
(7.57)\end{array}$ & 0.71 & 2.46 \\
\hline $\begin{array}{l}\text { Baddi Barotiwala } \\
\text { link road }\end{array}$ & $\begin{array}{c}11.5 \\
(19.39)\end{array}$ & $\begin{array}{c}6.0 \\
(13.59)\end{array}$ & 2.06 & 4.44 \\
\hline $\begin{array}{l}\text { Kalka Charnia link } \\
\text { road }\end{array}$ & $\begin{array}{c}34.0 \\
(35.46)\end{array}$ & $\begin{array}{c}22.5 \\
(30.11)\end{array}$ & 35.96 & 21.18 \\
\hline Control & $\begin{array}{c}43.0 \\
(40.93)\end{array}$ & $\begin{array}{c}22.5 \\
(28.16)\end{array}$ & 35.10 & 24.14 \\
\hline $\mathrm{CD}(p=0.05)$ & (7.91) & (7.29) & 7.43 & 5.171 \\
\hline
\end{tabular}

Figures in parentheses are angular transformed values 
link road and 22.5 in Kalka Charnia link road against 22.5 in control. The germination energy in National Highway 21-A was also at par with that in Baddi Barotiwala link road.The germination energy of seeds collected from Kalka Charnia link road was at par with control trees and higher than Baddi Barotiwala link road and National Highway 21-A.

The trend obtained in germination value of seeds collected from different sites was the same as that of germination energy. The germination value was lowest in National Highway 21-A i.e., 0.71 which was also at par with germination value (2.06) in Baddi Barotiwala link road. The germination value of seeds collected from Kalka Charnia link road (35.96) was higher than National Highway 21-A (germination value-0.71) and Baddi Barotiwala link road (germination value-2.06) and at par with control (germination value-35.10).

The germination speed was 2.46, 4.44 and 21.18 in seeds collected from National Highway 21-A, Baddi-Barotiwala link road and Kalka Charnia link road, respectively, against 24.14 in seeds collected from trees 200 m away from Kalka Charnia link road (control). The germination speed in seeds collected from National Highway 21-A and Baddi-Barotiwala link road was at par with each other and significantly lower than seeds collected from Kalka Charnia link road and control. Similarly, the germination speed of the seeds collected from Kalka Charnia link road was at par with the seeds collected from control trees.

3.2. Variations in seed germination parameters of Toona ciliata growing along roadside in $B B N$ industrial area of Himachal Pradesh

The germination of seeds collected from roadside trees in all the three sites was significantly lower than the seed collected from control trees i.e. $200 \mathrm{~m}$ away from road in Kalka Charnia link road (Table 2). The seed germination was 95.0, 97.0 and $96.5 \%$ in seeds collected from National Highway 21-A, Baddi-

Table 2: Variations in seed germination parameters of Toonaciliata growing along roadside in BBN industrial area of Himachal Pradesh

\begin{tabular}{lcccc}
\hline Sites & $\begin{array}{c}\text { Germi- } \\
\text { nation } \\
(\%)\end{array}$ & $\begin{array}{c}\text { Germi- } \\
\text { nation } \\
\text { energy }\end{array}$ & $\begin{array}{c}\text { Germi- } \\
\text { nation } \\
\text { value }\end{array}$ & $\begin{array}{c}\text { Germi- } \\
\text { nation } \\
\text { speed }\end{array}$ \\
\hline National highway & 95.0 & 85.5 & 114.88 & 43.92 \\
21-A (Baddi) & $(78.74)$ & $(67.84)$ & & \\
Baddi Barotiwala & 97.0 & 91.0 & 125.90 & 48.70 \\
link road & $(81.16)$ & $(72.74)$ & & \\
Kalka Charnia link & 96.5 & 93.5 & 128.32 & 45.02 \\
road & $(79.34)$ & $(75.34)$ & & \\
Control & 99.0 & 94.5 & 133.32 & 53.94 \\
& $(87.41)$ & $(76.88)$ & & \\
CD $(p=0.05)$ & $(5.88)$ & $(4.94)$ & 10.19 & 7.19 \\
\hline
\end{tabular}

Figures in parentheses are angular transformed values
Barotiwala link road and Kalka-Charnia link road, respectively, against $99.0 \%$ in Control. There were no significant differences in seed germination between different sites where seeds were collected from roadside trees.

The lowest germination energy was recorded in National Highway 21-A i.e., 85.5, followed by 91.0 in Baddi-Barotiwala link road and 93.5 in Kalka-Charnia link road, respectively, against 94.5 in control. The germination energy of seed collected from Baddi Barotiwala link road was at par with Kalka-Charnia link road. Similarly, no significant differences in germination energy were recorded in Kalka-Charnia link road and control.

The germination value was 114.88, 125.90, 128.32 in seeds collected from National Highway 21-A, Baddi-Barotiwala link road and Kalka-Charnia link road, respectively, against 133.32 in seeds collected from trees 200 m away from Kalka-Charnia link road (control). The germination value was found lowest in seeds collected from National Highway 21-A, whereas, germination values of seed collected from Baddi-Barotiwala link road and Kalka-Charnia link road were at par with control.

The germination speed of seeds was also found lower in seeds collected from roadside trees in three sites as compared to control where seeds were collected from trees $200 \mathrm{~m}$ away from Kalka-Charnia link road. The germination speed of seeds collected from different sites was 43.92, 48.70, 45.02 in seeds collected from National Highway 21-A, Baddi-Barotiwala link road and Kalka-Charnia link road, respectively, against 53.94 in control. The germination speed in seeds collected from National Highway 21-A, Baddi-Barotiwala link road and Kalka-Charnia link road were at par with each other. The germination speed in Baddi-Barotiwala link road was also at par with control.

3.3. Variations in seed germination parameters of Dalbergia sissoo growing along roadside in $B B N$ industrial area of Himachal Pradesh

The cumulative seed germination was $94.5,98.5$ and $97.5 \%$ in seeds collected from National Highway 21-A, Baddi-Barotiwala link road and Kalka-Charnia link road, respectively, against 99.5\% in seeds collected from trees 200 m away from road in Kalka-Charnia link road (Table 3). There were no significant differences in seed germination observed between different sites.

The lowest germination energy was recorded in Kalka-Charnia link road i.e. 64.0 followed by 67.0 in National Highway 21- A and 79.0 in Baddi-Barotiwala link road against 75.5 in control. No significant differences in germination energy were also observed between different sites.

The germination value of seeds collected from different sites was 181.12, 279.32 and 221.52 in seeds collected from National Highway 21-A, Baddi-Barotiwala link road and Kalka-Charnia link road, respectively, against 266.40 in seeds collected from trees $200 \mathrm{~m}$ away from Kalka-Charnia link road. 


\begin{tabular}{|c|c|c|c|c|}
\hline Sites & $\begin{array}{c}\text { Germi- } \\
\text { nation } \\
(\%)\end{array}$ & $\begin{array}{l}\text { Germi- } \\
\text { nation } \\
\text { energy }\end{array}$ & $\begin{array}{c}\text { Germi- } \\
\text { nation } \\
\text { value }\end{array}$ & $\begin{array}{l}\text { Germi- } \\
\text { nation } \\
\text { speed }\end{array}$ \\
\hline $\begin{array}{l}\text { National highway } \\
21-A \text { (Baddi) }\end{array}$ & $\begin{array}{c}94.5 \\
(78.43)\end{array}$ & $\begin{array}{c}67.0 \\
(57.72)\end{array}$ & 181.12 & 19.14 \\
\hline $\begin{array}{l}\text { Baddi Barotiwala } \\
\text { link road }\end{array}$ & $\begin{array}{c}98.5 \\
(84.52)\end{array}$ & $\begin{array}{c}79.0 \\
(63.32)\end{array}$ & 279.32 & 40.72 \\
\hline $\begin{array}{l}\text { Kalka Charnia link } \\
\text { road }\end{array}$ & $\begin{array}{c}97.5 \\
(81.93)\end{array}$ & $\begin{array}{c}64.0 \\
(53.20)\end{array}$ & 221.52 & 35.38 \\
\hline Control & $\begin{array}{c}99.5 \\
(88.17)\end{array}$ & $\begin{array}{c}75.5 \\
(60.47)\end{array}$ & 266.40 & 39.78 \\
\hline $\mathrm{CD}(p=0.05)$ & N.S & N.S & 37.72 & 5.27 \\
\hline
\end{tabular}

Figures in parentheses are angular transformed values

The germination value was lowest in seeds collected from National Highway 21-A as compared to other sites, whereas, germination value of seeds collected from Baddi-Barotiwala link road was at par with control.

The germination speed of seeds collected from different sites was found to be 19.14, 40.72 and 35.38 in seeds collected from National Highway 21-A, Baddi-Barotiwala link road and Kalka-Charnia link road, respectively, against 39.78 in control. The germination speed in seeds collected from National Highway 21-A was found significantly lowest as compared to other sites. No significant differences in germination speed were observed in other sites.

The seed germination in all the tree species under study decreased among sites where seeds were collected from roadside trees as compared to control.The seed germination of L. leucocephala was most affected as compared to other tree species. Highest reductions in seed germination of L. leucocephala were recorded in National Highway 21-A (90.7\%), followed by Baddi-Barotiwala link road and Kalka Charnia link road. The reductions in seed germination in $T$. ciliata and $D$. sissoo in roadside sites varied between 2.0 to 4.0 and 1.0 to $5.0 \%$, respectively, over control (Table 4).

The impact of auto-exhaust emissions on seed germination and seedling growth of roadside trees has been reported by various workers. Krishnaya and Bedi (1986) have reported the toxic effects of automobile exhaust on germination of Cassia tora and C. occidentalis and they also observed improvement in seed germination with increase of $60 \mathrm{~m}$ distance from the road. Among different tree species the highest reductions in seed germination were recorded in $\mathrm{L}$. leucocephala as compared to others (Table 4). One of the reasons for higher reductions may be the variations in the morphology of seed bearing structures present in these tree species. In L. leucocephala, the seeds are borne in the pods which have loose structures. On maturity sometimes the pods open resulting in falling of seeds. There is probability of toxic pollutants from auto-exhaust emissions entering the seeds through pods which may affect the seeds germination and plant growth. In $T$. ciliata the seeds are enclosed in capsules and are protected from the outer environment. The pods of D. sissoo are also very compact which prevent the pollutants to enter the pods.

Table 4: Comparative seed germination in different tree species growing along roadside in BBN industrial area of Himachal Pradesh

\begin{tabular}{|c|c|c|c|c|c|c|}
\hline \multirow[t]{2}{*}{ Sites } & \multicolumn{2}{|c|}{ L. leucocephala } & \multicolumn{2}{|c|}{ T. ciliata } & \multicolumn{2}{|c|}{ D. sissoo } \\
\hline & $\begin{array}{c}\text { Germination } \\
(\%)\end{array}$ & $\begin{array}{l}\text { Reduction over } \\
\text { control (\%) }\end{array}$ & $\begin{array}{c}\text { Germination } \\
(\%)\end{array}$ & $\begin{array}{l}\text { Reduction over } \\
\text { control (\%) }\end{array}$ & $\begin{array}{l}\text { Germina- } \\
\text { tion (\%) }\end{array}$ & $\begin{array}{c}\text { Reduction over } \\
\text { control (\%) }\end{array}$ \\
\hline $\begin{array}{l}\text { National highway 21-A } \\
\text { (Baddi) }\end{array}$ & $4.0(8.93)$ & 90.7 & $95.0(78.74)$ & 4.0 & $94.5(78.43)$ & 5.0 \\
\hline Baddi Barotiwala link road & $11.5(19.39)$ & 73.3 & $97.0(81.16)$ & 2.0 & $98.5(84.52)$ & 1.0 \\
\hline Kalka Charnia link road & $34.0(35.46)$ & 20.9 & $96.5(79.34)$ & 2.5 & $97.5(81.93)$ & 2.0 \\
\hline Control & $43.0(40.93)$ & - & $99.0(87.41)$ & - & $99.5(88.17)$ & - \\
\hline $\mathrm{CD}(p=0.05)$ & (7.91) & & (5.88) & & N.S & \\
\hline
\end{tabular}

\section{Conclusion}

The seed germination parameters of all the three tree species under study were affected by auto-exhaust pollutants. L. leucocephala was affected most by auto-exhaust pollution. The impact of auto- exhaust emissions was more prominent in National Highway 21-A, followed by Baddi-Barotiwala link road and Kalka-Charnia link road. The study indicated that plantation of fodder trees such as L. leucocephala should be avoided on roadside.

\section{References}

Abdullah, C.M., Iqbal, M.Z., 1991. Response of automobiles, stone and cement particulate matters on stomatal clogging of plants. Geobios 18, 196-201.

Ahmed, Z., Qadir, S.A., 1975. The effects of air pollution on stomata clogging, carbohydrates and chlorophyll 
contents in certain roadside plants. Pakistan Journal of Botany 7, 81-84.

ISTA, 1985. International rules for seed testing. Seed Science and Technology 13, 299-335.

Chattopadhyay, S., Gupta, S., Saha, R.N., 2010. Spatial and Temporal Variation of Urban Air Quality: A GIS Approach. Journal of Environmental Protection 1, 264-277.

Das, S., Prasad, P., 2010. Seasonal variation in air pollution tolerance indices and selection of plant species for industrial area of Rourkela. Indian Journal of Environment Protection 30, 978-988.

Dwivedi, A.K., Tripathi, B.D., Shashi., 2008. Effect of ambient air sulphur dioxide on sulphate accumulation in plants. Journal of Environmental Biology 29, 377-379.

Iqbal, M.Z., Shafiq, M., Kausar, A.S., 2001. Toxic effects of lead and cadmium individually and in combination on germination and growth of Leucaena leucocephala. Pakistan Journal of Botany 33, 551-557.

Krishnaya, N.S.R., Bedi, S.J., 1986. Effects of automobile pollution on Cassia tora L. and Cassia occidentalis L. Environment Pollution 40, 221-226.

Miles, C.D., Brandle, J.S., Danial, D.J., Chur-Der, O., Schnare, P.D., Uhlik, D.J., 1972. Inhibition of photosystem II in isolated chloroplast by lead. Plant Physiology Lancaster 49, 820-825.

Mondal, N.K., Panja, D., Das, C., Dey, U., Das, K., 2014. Impacts of vehicle exhaust black soot on germination of gram seed (Cicer arietinum L.) Communications in Plant Sciences 4, 01-09.

Nesamani, K.S., 2010. Estimation of automobile emissions and control strategies in India. Science of the Total Environment 408, 1800-1811.

Seyyed, M.S., Haniyeh, K., 2014. Some morphological and biochemical responses due to industrial air pollution in Prosopis juliflora (Swartz) DC plant. African Journal of Agricultural Research 8, 1968-1974.

Shafiq, M., Iqbal, M.Z., 2012. Effect of auto-exhaust emission on germination and seedling growth of an important arid tree Cassia siamea Lamk. Emirates Journal of Food and Agriculture 24, 234-242.

Shafiq, M., Iqbal, M.Z., 2007. Germination and seedling behavior of seeds of Peltophorum pterocarpum DC. Baker Ex K. Heyne growing under motor vehicle emission. Turkish Journal of Botany 31, 565-570.

Sumitra, G., Srivastava, D., Deshmukh, K., Dubey, P., 2013. Effect of Air Pollution on Chlorophyll Content of Leaves. Current Agriculture Research Journal 1, 93-98.

Tripathi, A.K., Gautam, M., 2007. Biochemical parameters of plants as indicators of air pollution. Journal of Environmental Biology 28, 127-132. 